Abstract ID: 109

\title{
Flooding impact on distribution of pathogenic bacteria in Pahang river
}

\author{
Fatin Hafawati Abd Razak ${ }^{a}$ | Noor Faizul Hadry Nordin ${ }^{b}$ | Jalal Ahmed Khan Chowdhury ${ }^{c}$ | \\ Kamaruzzaman Yunus ${ }^{\mathrm{C}}$ \\ ${ }^{a}$ Department of Biotechnology, Kulliyyah of Science, International Islamic University Malaysia \\ ${ }^{b}$ Department of Biotechnology Engineering, Kulliyyah of Engineering, International Islamic University \\ Malaysia \\ 'Department of Marine Science and Technology, Kulliyyah of Science, International Islamic University \\ Malaysia
}

Introduction: Pahang River is one of the important inland aquatic biodiversity resources that provides major economic activities along the river. It is an excellent source of food and habitat for organisms including microorganisms leading to higher bacterial diversity. This analytical study determines the impact of flooding event to the bacterial distribution and pathogenic bacteria in the river. Methods: Sampling was done during pre-monsoon and post monsoon seasons. Water samples were taken at 19 stations along the Pahang River. Bacterial was isolated from the water samples using cultivation method. Subsequently DNA from the isolated bacteria was extracted using conventional method. 16s RNA was used in the study to amplify the bacterial DNA. Following restriction fragment length polymorphism (RFLP), selected bacteria were sent for sequencing to the First Base company. The sequences were then analyzed using blast from NCBI to obtain the bacterial name. Results: Here, we evaluated the colony forming unit (CFU) and the presence of potentially pathogenic bacteria in the river before and after the flood event in 2014. The CFU calculated was lower before the flooding event and Bacillus sp. were found in many of the water samples. After the flooding event pathogenic bacteria such as Klebsiella pneumoniae, Serratia marcescens and Enterobacter cloacae were discovered while the CFU calculated was shown to be higher. Conclusions: The pathogenic bacteria diversity was increased after the flood in 2014 in Pahang River. The river became contaminated with various types of potential human bacterial pathogens which might pose a health risk to the public.

KEYWORDS: Pathogenic bacteria, bacterial distribution, Pahang River, flooding event 